\title{
School Failure in the Perception of Adolescents, Parents and Teachers
}

\author{
Fernanda Aparecida Szareski Pezzi - Universidade do Vale do Rio dos Sinos, São Leopoldo, Brasil \\ Tagma Marina Schneider Donelli - Universidade do Vale do Rio dos Sinos, São Leopoldo, Brasil \\ Angela Helena Marin - Universidade do Vale do Rio dos Sinos, São Leopoldo, Brasil
}

\begin{abstract}
This study aimed to understand school failure, defined as the distortion between age and school year of two or more years of teaching, through the perception of adolescents with a history of school failure as well as their parents and teachers. This is a qualitative, descriptive, and cross-sectional study. The participants consisted of three distinct groups: 35 adolescents, 11 parents and three teachers. The instruments used were an initial contact sheet as well as focus groups. For the content analysis three categories and their subcategories were derived related to the purpose of the study. The results point out to the complexity of school failure, revealed especially in the statements of teachers. However, it is still prevalent the discourse of personal and family blame among adolescents and their parents. It is evident the resulting suffering and the clinical and social consequences of school failure.

Keywords: school failure, failure, elementary school
\end{abstract}

\section{O Fracasso Escolar na Percepção de Adolescentes, Pais e Professores}

\begin{abstract}
Resumo
Este estudo teve como objetivo compreender as causas e a vivência do fracasso escolar, entendido como a distorção entre idade e ano escolar de dois ou mais anos de ensino, por meio da percepção de adolescentes com histórico de fracasso escolar, bem como de seus pais e professores. Trata-se de uma pesquisa qualitativa, descritiva e de caráter transversal. Os participantes constituíram três grupos distintos: 35 adolescentes, 11 pais e três professoras. Os instrumentos utilizados foram uma ficha de contato inicial e grupos focais. Para a análise de conteúdo, derivaram-se três categorias e suas respectivas subcategorias relacionadas ao objetivo do estudo. Os resultados apontaram para complexidade do fracasso escolar, revelada especialmente na fala das professoras. Entretanto, ainda prevalece o discurso de culpabilização pessoal e familiar entre os adolescentes e seus pais. Destaca-se o sofrimento decorrente da vivência do fracasso escolar e suas consequências clínicas e sociais.

Palavras-chave: fracasso escolar, reprovação, ensino fundamental
\end{abstract}

\section{El Fracaso Escolar en la Percepción de Adolescentes, Padres y Maestros}

\begin{abstract}
Resumen
Este estudio tiene como objetivo comprender las causas y la experiencia del fracaso escolar, entendido como distorsión entre edad y año escolar de dos o más años de enseñanza, por medio de la percepción de adolescentes con un historial de fracaso escolar, así como de sus padres y maestros. Es una investigación cualitativa, descriptiva y de carácter transversal. Los participantes formaron tres grupos distintos: 35 adolescentes, 11 padres y 3 maestros. Los instrumentos utilizados fueron una ficha de contacto inicial y grupos de enfoque. Para el análisis de contenido resultaron tres categorías y sus respectivas subcategorías relacionadas con el propósito del estudio. Los resultados apuntan a la complejidad del fracaso escolar, revelado especialmente en el discurso de los maestros. Sin embargo, aún prevalece el discurso de culpa personal y familiar entre los adolescentes y sus padres. Se destaca el sufrimiento resultante de la experiencia del fracaso escolar y sus consecuencias clínicas y sociales. Palabras clave: fracaso escolar, reprobación, enseñanza primaria
\end{abstract}

The school failure theme continues to worry professionals who work in the school context, and it is an important object of study and research (Faissol \& Bastos, 2014). In Brazil, the distortion rates of age-grade/ year $(23.6 \%)$, failure $(10.3 \%)$, and school withdrawal $(3.1 \%)$ in elementary school continue to be significant and worrisome (IBGE, 2010). These data seem to be persistent and inseparable from education history and from the process of education in the country, especially in the popular classes (Bassani \& Pinel, 2011; Paula \& Tfoni, 2009; Patto, 1990). In addition to education, psychology also is present in this discussion due to a concern about prevention and treatment of children and adolescents who fail at school (Zucoloto \& Patto, 2007).

It is known that when failing, the student turns out to have their school routine marked by displeasure, moved by the fear of failure (Costa, Lima, \& Pinheiro, 2010), as well as having their self-confidence (Millones, Leeuwen, \& Ghesquière, 2013), self-esteem (Kamal \& Bener, 2009; Lopes \& Teixeira, 2012; Pershey, 2010), and motivation shaken (Martinelli \& Genari, 2009). It is also remarkable the propensity to acquire habits harmful to health, such as the use of tobacco (Dhavan 
et al., 2010; Gran \& Nieto, 2013), alcohol and other drugs (Kamal \& Bener, 2009), get involved with crime and experience teenage pregnancy (Rumberger, 2011), which can affect the educational and professional choices later (Mocetti, 2012).

Such evidence denote how much the family, teachers and the school are still not prepared to deal with school failure (Bossa, 2002) and highlight the need for a broad and integrated look between the clinical and educational work (Travi, Oliveira-Menegotto \& Santos, 2009). In this sense, different researchers have worked to know the students' vision on the school failure (Farid, 2012; Guler, 2013; Hancer, 2012, Lagana-Riordan et al., 2011; Oliveira \& Macedo, 2011; Osti \& Brenelli, 2013), as well as their family (Chechia \& Andrade, 2005; Costa et al., 2010; Marchesi \& Lucena, 2004; Martinelli \& Aguena, 2011; Neves \& Santiago, 2009) or their teachers (Asbahr \& Lopes, 2006; Bray \& Leonardo, 2011; Gomes \& Souza, 2009; Hjörne \& Säljö, 2014; Kamal \& Bener, 2009). However, there are few studies that investigate and relate all the mentioned systems (Ireland et al., 2007; Marchesi \& Lucena, 2004; Neves \& Almeida, 1996).

The studies which sought to understand the students' perceptions highlighted that it is common the expression of feelings of guilt and accountability for school failure (Almeida, Miranda, \& Guisande, 2008; Farid, 2012; Martini \& Del Prette, 2005; Oliveira \& Macedo, 2011; Osti \& Brenelli, 2013). Similarly, the parents related the successive school failures with lack of school motivation and maturity of their children, also pointing to the structure and functioning of the education system (Marchesi \& Lucena, 2004; Neves \& Almeida, 1996). However, many revealed not knowing what to do so that their children could get a good school performance and were little involved with school issues (Chechia \& Andrade, 2005; Costa et al. 2010; Lahire, 2004; Neves \& Santiago 2009). Teachers, in turn, attributed the school failure, above all, to the students themselves and also their families (Asbahr \& Lopes, 2006; Bray \& Leonardo, 2011; Gomes \& Souza, 2009; Hjörne \& Säljö, 2014, Kamal \& Bener, 2009; Ireland et al., 2007; Neves \& Almeida, 1996). Asbahr \& Lopes (2006) noted that little did the teachers mention teaching or school work as also responsible for school difficulties.

Considering this context, Bossa (2002) highlighted that the school, in the search for ideal students, ended up projecting in real students its fault for the impossibility of the purposes for which it is intended. So those who do not learn end up being rejected and excluded, which generates suffering. Many children referred to psychological treatment mention and show the intensity and consequences of suffering from the school failure, because once faced with learning difficulties, they are seen as incapable and disabled, being marginalized and oppressed by the school system (Bossa, 2002). Similarly, the experience of school failure also causes pain in their parents, especially with respect to negligence and disregard with which they are treated when seeking for a place or even when willing to participate more actively in the education of their children (Oliveira, 2002).

Considering the above mentioned, Vieira et al. (2012) alerted to the importance of considering both external school variables related to biological, social, and emotional issues of students and their families and internal school variables, presented in the school context, once they all interact in school failure. As Bassani \& Pinel (2011) warn, even if psychology emphasize the subjective aspects, this phenomenon needs to be understood from the social structure, as produced by a relationship network including the students themselves, their families and their teachers, because what happens in one of those areas will interfere with or modify the other ones (Bossa, 2002). Thus, the present study aimed to understand the causes and the experience of school failure, understood as the distortion between age and school year (Brazil, 1996, 2010a, 2010b) of two or more years of education (SMED-SL, 2012), through the perception of adolescents with a history of school failure, as well as of their parents ${ }^{1}$ and teachers. We favor the term perception to contemplate the different opinions that each participant expressed (Marchesi \& Lucena, 2004).

\section{Method}

\section{Design}

This is a descriptive, cross-sectional research, with a qualitative approach. According to Flick (2009), qualitative studies are focused on the meaning that participants relate to the issue being studied and imply an interpretative and naturalistic attitude from the researcher. One of the advantages of the qualitative study is the possibility of looking at the same phenomenon from different points of view or perspectives,

\footnotetext{
${ }^{1}$ In this study, the term "parent" is used to refer to the mother and the father.
}

Psico-USF, Bragança Paulista, v. 21, n. 2, p. 319-330, mai./ago. 2016 
since it recognizes the unique role of each subject as a producer of knowledge (González-Rey, 2002).

\section{Participants}

Three distinct groups participated in this study. The first, consisting of 35 adolescents, was subdivided into five groups; the second, consisting of 11 parents, was subdivided into two groups; and the third consisted of three teachers. We considered the composition of the groups as suggested by Barbour (2009).

The adolescents were 14 to 17 years old $(\mathrm{M}=$ 15.6 SD $=0.73$ ), being 18 male and 17 female. All were enrolled in elementary school in a municipal school of the city of São Leopoldo/RS, Brazil, and were selected by convenience, considering the criterion of registration in a class of accelerated learning ${ }^{2}$ due to distortion of age and school year (Brazil, 1996, 2010a, 2010b) of two or more years of education (SMED-SL, 2012). As this school had two acceleration classes, adolescents of both classes were invited to participate and those who accepted composed the groups.

All parents with a child enrolled in the acceleration classes were also invited to participate in the study $(\mathrm{N}$ $=41$ ), and those interested composed the group of 10 mothers and one father. Most of them had incomplete elementary school $(\mathrm{n}=8)$, paid work $(\mathrm{n}=8)$ and four or more children ( $n=7)$.

The group of teachers was composed of three participants, who have agreed to participate in the study, from the total of four working in accelerated learning classes. They had, on average, 12 years of teaching. Two of them had been working for three years in acceleration classes, while it was the first experience with these classes for the third one.

\section{Instruments}

Initial Contact Sheet: this instrument aimed to register the data of the adolescent, school and teacher, as well as the address and phone number of the families to contact later.

Focus Group: This instrument aims to obtain data through discussion, from which participants express their perception about school failure. This is an instrument that has been used in different areas of knowledge and circumstances under which, from

\footnotetext{
${ }^{2}$ This project aims to develop new pedagogical practices for students who could not benefit from education in regular time, as per the National Education Guidelines and Framework Law (LDBEN) 9.394/1996, resolution CNE/CEB 4/2010 and the legal opinion CNE/CEB 7/2010 of the National Council of Education.
}

a guide with topics (script), the researcher stimulates interaction among the participants (Barbour, 2009). The Focus Group allows participants to feel welcomed and supported by the group, and when used to investigate a potentially embarrassing subject for students, parents and teachers, it facilitates expression and minimizes the omission of data produced by any embarrassment, since all are united by the phenomenon being investigated. In the present study, the discussion topics focused on the relationship among students, family and school, seeking to understand the causes and the experience of the school failure in each one of the groups. The focus groups had the presence of a moderator (researcher) and also an assistant moderator.

\section{Procedures}

This is a descriptive, cross-sectional research, with a qualitative approach and is part of a larger research, entitled "Fracasso escolar: sintoma e/ou reatividade ao sistema de ensino?"3, coordinated by Profa. Dra. Angela Helena Marin, which aims to assess the individual, family and school factors and their interrelation with the production of the school failure in adolescents of the elementary school. This study has been approved by the Research Ethics Committee (CEP) of Universidade do Vale do Rio dos Sinos under the Protocol no. 12/08, so all the necessary principles and ethical care needed for studies with human beings were assured as per resolution 466/12 from the National Health Council.

Initially, we contacted the Municipal Secretary of Education of São Leopoldo/RS to present the study proposal and obtain authorization for its conduction. Once the authorization had been granted, a municipal school which had classes of accelerated learning was contacted. After the school accepted to participate, a letter of consent was signed by the school board. Later, we invited adolescents with a history of school failure. To those interested in participating, we handed a consent which their parents should also sign, in addition to a brief initial contact sheet, used to contact them later. Similarly, teachers were invited to participate in the study and signed the consent.

We then checked with the school board the availability of rooms and timetables for conducting the focus groups. As the group is the unit of analysis, we decided to ensure that its participants shared at least

\footnotetext{
${ }^{3}$ This project was financed by the National Council of Scientific and Technological Development (CNPq) by public call MCTI/CNPq/ MEC/CAPES no. 18/2012 - Humanities, Applied and Social Sciences public notice.
} 
one characteristic (Barbour, 2009). The groups with adolescents and teachers took place in the afternoon, while the groups with parents were scheduled on the night shift, so they could participate.

At the beginning of each focus group, a rapport was conducted, ensuring the ethical principles of studies with humans. The groups consisted of three to eight participants, considering the importance of it to be small enough so that everyone could share their perceptions and large enough to contemplate the diversity among them (Oliveira \& Freitas, 1997). The duration of each focus group ranged from 30 to 100 minutes.

The material produced in the groups was recorded in audio, transcribed in its entirety and examined through qualitative content analysis (Bardin, 1977; Laville \& Dionne, 1999). We adopted the model of thematic categories, which recommends the following steps: 1) pre-analysis (steps included: organization of data, readings, development of indicators, and material preparation); 2) exploration of the material (it consists essentially in codifying the material); and 3) treatment of the results, inference and interpretation (meaning attribution to data).

The categories were defined previously as per the discussion topics, and the subcategories were derived from the data itself, which were analyzed using the Nvivo10 software. For the agreement calculation, two judges rated separately $20 \%$ of the total speeches classified in each focus group ${ }^{4}$. The index among the judges was $87 \%$ for group with adolescents, $96.5 \%$ for the group with parents, and $82.1 \%$ for group with teachers. These rates are considered excellent, according to Robson (1995).

\section{Results}

To reach the objective of the present study, three categories were established and subcategories were derived, as follows: 1) causes of school failure, which included subcategories a) students, b) families, c) institutional issues, d) social aspects; 2) experience of failure, which was sub-categorized in a) feelings, b) consequences of failure; and 3) future prospects of those who fail at school, which did not include subcategories. The theme categories and sub-categories derived from content analysis, illustrated with speeches by the

\footnotetext{
${ }^{4}$ The speeches of all groups held, respecting the division among adolescents, parents and teachers, were considered for this calculation.
}

participants of each one of the groups, are presented below. The speeches were not identified to preserve their identity. To refer to the focus groups of adolescents, we used the symbol AG, accompanied by the number 1 to 5 , indicating the group in which the speech was made. We also used the abbreviations PG for the group with parents, accompanied by the numbers 1 and 2. The causes of school failure: "The professor entered the room, I would leave!"

In this category, the speeches were divided into four subcategories that indicate to whom or to which were attributed the causes of school failure, as follows: 1) students, 2) families, 3) institutional issues, and 4) social aspects. The first subcategory, which refers to the scapegoating of the students, was the most emphasized by adolescents and their parents. Among adolescents, the lack of interest was remarkable: 'Lack of interest!", "I didn't like to come to school!" (AG1; AG2; AG3; AG4; AG5); absence: "I missed a lot" (AG2; AG3; AG4; AG5); the difficulties to learn: "We have difficulties in some subject and fail" (AG3); and behavioral issues: "I argued with the teachers and fought a lot." (AG1),"I used to be more on the street than in the classroom. The professor entered the room, I would leave!" (AG1).

Similarly, the parents reported aspects related to their children and pointed the lack of interest: "Lack of interest in studying!" (PG1; PG2), "I think some don't want to do anything at all. It's not because of intelligence. "(PG1); and laziness: "Pure laziness" (PG1; PG2). They also highlighted behavioral aspects: "She was very shy!" (PG1; PG2), "He's ashamed of standing up and talking" (PG2), "My son only thinks about dating" (PG2), "Teenage stuff! The chatterbox in the room! But if he gave it all he had, he would have had a chance to pass" (PG2). It should be noted, finally, that only one mother referred to the issue of cognitive potential: "My daughters were a little dumb!" (PG1).

Teachers, in their turn, understood this phenomenon as a result from a number of reasons: "T think it has to do with family, school. Several issues make the student fail! It's not the teacher or the student. I think it's a number of problems". However, they also highlighted the immaturity of their students: "Their own immaturity"; the indiscipline: "They were 60 students who had already failed several times, but not for cognitive issues, only because of discipline. They were students totally undisciplined!'; and learning difficulties: "Learning difficulties."

Regarding the subcategory "family", which is about family aspects considered responsible for school failure, adolescents highlighted the issue of their parents' education, quarrels and family conflicts: "The 
quarrels at home, family conflicts!" (AG3), "Some parents didn't go to school, then the kids don't want to study either!" (AG1).

The parents mentioned that they were used to giving advice, but it was up to their children to follow it or not: "I have already explained to them that the year lost is not ours. It is their year, even though we pay for the clothes, footwear, school supplies, everything!" (PG2). They stressed the difficulty they have in monitoring the school life of their children because they did not complete the elementary school: "I can't help anymore! I only studied until the 3rd grade, so I can't help!" (PG2), "I say: do as I say, not as I do!'” (PG2). They also mentioned that they could not follow the school life of their children because of their own heavy workload: "He missed 36 classes, but I didn't know. I was working and he had a girlfriend. He would go to her bouse" (PG2).

The teachers pointed the lack of family structure and reference: "Their family disrupt is sometbing! At one moment, he is living with one, then with the other! "And the low educational level of the parents: "So they are like this, what do you expect? What structure is that? The newspaper once did a survey here and $90 \%$ [of the parents] did not complete elementary school. The data are alarming like this!"

In the subcategory "institutional issues", which encompassed the school characteristics related to school failure, the adolescents talked about teachers and the way they were taught: "Some [teachers] even wanted to teach, some didn't. For some I even had to shout: oh teacher, come here teach me. Can't you see I'm in need?" (AG1), "Some annoying teacher who the student does not like." (AG3), "T failed because of her [teacher]. She didn't like me, didn't like at all!" (AG4). Eventually, they also reported the contents of a specific discipline: "The subject." (AG1; AG4).

The parents followed the same logic, talking about the teachers, in particular about their performance in the classroom: "I think having a good teacher also contributes" (PG2). They also reported aspects of teacher-student relationships, from what their children told them: "Once she heard from a professor like this: there are 40 students in here, do you think I'm going to explain to you 4-5 times?" (PG2), "She askes for the second time. If the teacher comes with two stones in their hands, then she bolds back. She no longer studies the subject" (PG2).

The teachers highlighted the fact the student say that they do not learn with a specific teacher, hating the subject due to the regent's professor and the importance of the teacher having flexibility, plus getting to know how each student learns: "I have to find out several alternatives for that student. There are teachers who have a methodology and have been following for eight, 10 years the same methodology. I approach it in different ways, because I realize that sometimes it is not the same way with the other and we have to take care of it ". Eventually, the teachers also stressed the importance of affection to prevent school failure: "To have this affection among students, win their hearts! See us here. We have several colleagues who are doing a beautiful work of involving these students". The teachers also referred to the organization of the school and pointed out that the curriculum did not allow them to approach the student to know them better: "What happens: they have nine, 10 teachers. It's a very great rotation! You stay two hours in there with that student and will stay with them again only next week. You don't know the story of that student." They also mentioned the workload imposed on teachers, as well as the lack of moments of dialog among them to plan joint actions: "The history teacher teaches seven classes. How will we talk? I think this is a very complicating factor"; and they talked about the project of accelerated learning: "There's something wrong that has been created here at school a couple of years ago: if it doesn't work in the regular grades, they send the students to Acelera, as if they were not normal, right? Send them to Acelera! Send them to see if they straighten up".

Finally, in the fourth subcategory, "social aspects", we allocated the aspects related to social and cultural issues identified as causes of school failure. The adolescents only referred to drugs and teen pregnancy: "Drugs" (AG2), "teenage pregnancy" (AG2; AG5). The parents pointed out the need for working, as an adolescent tells their mother: "Mom, I'm going to study only until high school. I'm going to have to work" (PG2). While the teachers talked about all aspects mentioned by adolescents and their parents. They highlighted the issue of teenage pregnancy, the importance of working and the shame of some labels that are attributed to adolescents because they live in a specific neighborhood: "They carry with them that label and certain shame of it: that they are a thief, a pothead!", "Pregnancy too early. These girls soon stop studying", "the first value in the community is working, and it is not having education or finishing the elementary school to then get [a job]".

The experience of failing: "A horse among the little ones"

This category relates to how failure was experienced in each group studied, being approached from two sub-categories. The first of these, "students' feelings", referred to the adolescent's feelings who failed, their parents and their teachers; and the second, "the consequences of failure" emphasized the possible implications of this experience. 
With respect to the first subcategory, the adolescents reported that when facing the failure they felt: "Sad" (AG2), "Bad" (AG1; AG3), "useless, worthless. I have to do it all over again, for not having done right!" (AG5), "Discouraged" (AG1), "a horse among the little ones" (AG3). They also mentioned that they received advice or punishment from their parents: "Moms tell that they threw a year away" (AG2), "my dad grounded me" (AG3).

The parents, in their turn, confirm how the experience of failure felt like something hard for adolescents. The reports emphasized feelings like shame and regret for not having done the work: "Ashamed. A little relapsed" (PG1), "He locks himself in the bedroom. He won't see me" (PG2), "Ah! He said he didn't know it would hurt so much not to hand in schoolwork." (PG2). However, they demonstrated a conformist stance: "But that's it! It's good to learn!” (PG2).

The teachers stressed that, overall, the students felt very badly when they failed: "I think they feel like a loser", at the same time they realized that students sought to conform to the situation: "Really, teacher, I was up to many things!' According to them, in the accelerated classes the students were aware of the following: "They were aware that was their fault in the sense that they stopped to work or for family issues and conflicts. Sometimes there was even student fight, like messing with someone from the neighborhood, be sworn to death and having to get out of school!"

As for the subcategory that addressed the "consequences of failure", adolescents stressed the withdrawal and evasion: "Because the students who fail do not want to study anymore." (AG1), "I'd give up my studies." (AG1). In addition, they complained about the prejudice they lived for having failed: "That one is stupid!" (AG1; AG2; AG3; AG4).

Parental speeches also pointed out the withdrawal and evasion: "So many times in the 5 th grade that he gave up" (PG1). They also referred to the shame and discomfort that their children felt: "[he] felt a giant" (PG1), "I was ashamed of my classmates" (PG1).

The teachers already highlighted how the students demonstrated insecurity and shame for having failed: "It's a lot of insecurity, this is what failure brings. So I think that's too strong!", "It seems that it creates some sort of blockade: as I haven't learned so far, I will never learn!' They also mentioned the prejudice: "They are excluded from relationships. About that I don't have the slightest doubt. I felt it and it burt in my heart!"; and evasion: "They would evade or stop studying, discredit the school and continue without that student identity". Eventually, they highlighted the discredit by the parents because of so many failures: "What we see, initially, is a total discredit by their parents: they don't learn, they failed, they only give me problems!"

Future perspectives of those who fail at school: "Students who fail don't want to study anymore, thus they can't get a job!"

In this category, we included the speeches relating to future possibilities of those who experienced school failure during their education. The adolescents recognized the importance of education to get a good job: "Studying is the student's future. A guy starts working and then: what grade are you in? I'm in 6th grade. He won't work! Even to pick up trash on the street you already have to be educated!" (AG2). The reviews were discrepant among those who didn't want to study anymore and those seeking work: "I think of working and that's it!" (AG2), "I don't want to study anymore." (AG2); and those who dreamed of a profession: "I want to serve the military, you know? I'm doing my best to get there" (AG2).

The parents also recognized the importance of studying to get a job with a higher pay: "He will have to study to be able to work better" (PG1). At the same time, they related future prospects to the characteristics of each person: "It is pretty much up to the person!" (PG2), but they stressed the importance of having a diploma: "Because I can have a better idea what you studied and I have to shut me up because I can't present it" (PG2). They pointed out that they seek to alert their children for them to study and for them not to follow the same path they followed: "If I had the chance, I would have studied. I could be doing better today than in a kitchen, in a business I wouldn't have to get stressed. I don't want him to do the same thing as me." (PG1).

The teachers reported how the students were recognizing the importance of studying to have a better life. A teacher, mentioning what a student in the classroom said when he saw bakers working in the sun: "Hey, teacher, I'm glad I'm studying because that would be my future!" They stressed that they have been working to try to educate students so that they will not repeat the story of their parents, particularly with regard to teenage pregnancy and the naturalization of domestic violence: "As with pregnancy, women getting beaten in the neighborhood is not something unusual."

\section{Discussion}

The present study investigated the perception about the causes and the experience of school failure among adolescents with a history of school failure, 
their parents and teachers. Discussing about school failure from the account of the protagonists, namely students, allows for the dismantling of some prejudices, as well as going beyond school complaint, opening up new possibilities to think about the relationship among school, learning and students (Caldas, 2005). In addition, including the school and family contexts in this discussion allows for the understanding of the phenomenon considering its complexity.

The results of this study showed that both adolescents and their parents and teachers showed individual, family, social, and institutional causes for school failure. However, it prevailed among adolescents and their parents the accountability of students (Guler, 2013; Oliveira \& Macedo, 2011; Osti \& Brenelli, 2013) and their family (Mocetti, 2012; Oliveira \& Macedo, 2011), which corroborates findings from other studies. Similarly, teachers referred to students and their families, confirming the literature (Asbahr \& Lopes, 2006; Bray \& Leonardo, 2011; Gomes \& Souza, 2009; Hjörne \& Säljö, 2014; Kamal \& Bener, 2009; Neves \& Almeida, 1996), but expanded their understanding, pointing out to institutional and social issues about the context in which the participants were in, which they believed that interfered in the way the system was organized and produced school failure.

It should be noted that when talking about the families, the idea that prevailed in the groups was that the parents, most of whom had incomplete elementary school, could not help their children according to their education level. Such data show a mismatch with the proposed by Lahire (2004), who mentioned that parents can assist in the learning process by means of transmission of values that refer to the importance of studying, of knowing how to read and write. However, some of the parents have shown not knowing what to do for their children to be interested in school, which converges with the data of the study conducted by Neves \& Santiago (2009), in which a mother revealed that she beat her daughter and grounded her, but nothing would do her to get a better school performance. So, parents often do not have guidance on how to act with their children in relation to school involvement and a partnership with the school would be beneficial in this regard.

The circularity that one realizes between the low educational level of the parents and a possible low schooling of children, on the basis of what can produce from the school failure, refers to a broader reflection. Although it was not a focus of this study, the experiences of school failure of parents seem to point to a social and cultural dimension that goes beyond the family limits, and that concerns the structure of the education system. In this perspective, Patto (1990) states that the explanations of school failure based on the theories of deficit and cultural differences need to be reviewed from the knowledge of the school mechanisms that are producers of learning difficulties. According to the author, the school can impede the learning of students considered poor, since the prejudice "structures processes and practices that consist from decisions related to educational policy to the daily relationship of teacher with students" (p. 408).

With regard to institutional issues related to school failure, adolescents and their parents questioned the attitudes of some teachers, such as the fact of not explaining the content, the lack of will to teach and the way they treated students who required further explanation to understand the content. Such aspects have also been singled out as the cause of failure by students participating in the study of Ireland et al. (2007). Affectivity in teacher-student relationships was also recognized as important in the teaching-learning process, which is pointed out in the literature as a protective factor for failure (Nunes, Pontes, Silva, \& Dell'Aglio, 2014; Osti \& Brenelli, 2013). In this sense, Osti \& Brenelli (2013) highlighted that often school failure stems from the pedagogical practice, from the methodology and from the teacher-student relationship, but they warn that they cannot be restricted to these.

Reflecting on the teacher-student relationship as a two-way street is necessary: students recognized themselves as uninterested and identified the same disinterest in their teachers. In this sense, the circularity of the phenomenon can be considered again, evidenced by the data, since some students are turned into losers due to their personal characteristics and mainly their social characteristics (Patto, 1990). Because they are students considered prone to fail, it eventually happens at school a naturalization of the phenomenon by all involved (Patto, 1990).

The teachers were aware of this process, relating the school failure to the teachers' own aspects and institutional issues, indicating that the way they organized the curriculum and how they established the relationships, either with students or colleagues also influenced the academic performance of the students. Thus, we can confirm that school failure turns out to be inevitable in the current educational system, imposing the need to think about new pedagogical practices and educational 
policies that aim to reduce the rates of school failure, such as the accelerated learning classes, mentioned by the teachers. On the other hand, they also revealed the importance of seeking to understand how each student learns what is important, once Damiani (2006) found that when an instructional speech is present in school directed to the development of the potential of students, school performance is favored.

Added to these issues, the social aspects were reminded in all groups, with emphasis on drugs, teenage pregnancy and the need to work due to financial shortages as causes of school failure. Specifically with regard to drugs, Gran \& Nieto (2013) highlighted that the adolescents who smoked cigarettes were those who had a history of school failure. More aggravating, Gauffin, Fridell, Hesse \& Hjern (2013) pointed out that the experience of school failure can also influence the involvement with illicit drugs. However, it is important to note that on the issue of chemical dependency there is a difficulty in defining whether its use is the cause or consequence of school failure, considering the correlational dimension of many studies.

When considering the experience of school failure, we noted a similar perspective among the groups analyzed. The adolescents talked about the sadness and suffering arising from the rejection, as well as the desire to give up and quit school. They also referred to the lack of motivation to continue studying and the feelings of futility and waste, in addition to the stigma of dumb, which corroborates the idea of Bossa (2002) about the suffering generated by the school failure. Similarly, the devaluation and guilt feelings were prevalent, confirming data from Osti \& Brenelli (2013), which highlighted the sense of disbelief among the students, which nourishes low expectations about their performance and academic progress. Such aspect could be observed in one of the groups of adolescents, most of whom remained apathetic and silent when they were invited to take a break. They were sitting, stating that they would rather be there along with other classmates.

School failure also caused suffering to parents. Many of them said they sought to assist their children in schoolwork, but sometimes they could not due to not receiving a proper pedagogical orientation or due to their low education level (Chechia \& Andrade, 2005). At the same time, although they also experience the pain of rejection, they ended up believing that failure would make their children dedicate themselves more to their studies and have a better behavior at school, corroborating the findings of Jacomini (2010). The teachers have highlighted the blockade, the insecurity and the disbelief that these students felt in school and conveyed to their families. Regarding future prospects of those who fail at school, we found that all participants mentioned the importance of studying in the current society. In this sense, the teachers indicated that they sought to rescue in adolescents the interest in studying, since, if the accelerated learning project did not exist at school, many would have evaded or joined the labor market, without even completing elementary school. Among adolescents, the opinions were divided. It was possible to observe those who remained at the school as a matter of obligation, they did not know what they wanted and appeared to be unmotivated, and those who thought in reconciling study and work and even enter university. Parents already referred to the importance of completion of elementary school, noting that they talked and tried to warn their children so that they did not repeat their own life stories.

From this perspective, some studies (Faissol \& Bastos; 2014; Osti \& Brenelli, 2013) stressed the importance of rescuing the self-esteem and motivation of students who have failed several times to encourage them to remain in school and establish life goals. Such work has proven to be crucial once the school failure ultimately influence the subsequent educational choices and discourage the building of future perspectives in different life areas (Lopes \& Teixeira; 2012; Mocetti, 2012; Nunes et al. 2014).

On the other hand, it is worth mentioning Amaral's (2010) study, which aimed to analyze the role of education of students of a class considered "weak" by the school team after 25 years. The author concluded that the traumatic experiences and stresses experienced during the process of education were not necessarily related to personal and professional developments little satisfactory. Therefore, the experience of school failures can trigger different effects, feelings and behaviors in each individual.

From the considerations submitted concerning the causes and the experience of school failure, it is possible to highlight that many aspects are interconnected in its production. Although it is known how psychology and education are historically shrouded in the understanding of this phenomenon, it is believed that studies like this, which consider the different actors involved in the issue, are still important to understand how it is perceived and experienced at the present time and to reveal the resulting suffering, enabling a more realistic reflection about its production. The results found, especially 
among adolescents and their parents, reinforce how historically repeated are the speeches which are or have already been dismissed on the individualization of school failure. In the work of Patto (1990), for example, the author has already revealed the complexity and the social, cultural, economic implications and policies involved in the production of this phenomenon. So, we question about what contributes to the scapegoating of the student and their family remaining, instead of the relationship among its different actors. Angelucci, Kalmus, Paparelli \& Patto (2004), when highlighting the existence of studies in this perspective, complain about the strength of this psychology concept that does not overtake the common sense, not contributing to the advancement of knowledge in the field.

In this sense, we believe that the present study brings as a contribution the look and the understanding of teachers who have managed to work with the complexity of school failure and, therefore, bring a new meaning to their pedagogical practice. We highlight how this look made a difference for students and their families, because many of the families, when their children started at the accelerated learning, would see for the first time a child completing elementary school. As limitations, it should be noted the small number of teachers who participated, as well as the non-inclusion of members of the school management in this discussion.

Finally, it should be noted that psychology has much to contribute to education. Perhaps not with the commitment to reports, opinions and referrals, but acting together in the school context, listening to the students, their parents and teachers who are suffering and need to be guided and assisted in overcoming the school failure. As seen, due to the complexity of the phenomenon, when the student fails, the family, teachers and the school also fail, which has consequences for society, because it is also produced and repeated by it. Therefore, one of the challenges to psychologists who work in the school context is to consider the different actors and aspects that participate in the production and reproduction of the failure in the articulation of school interventions with a view to health prevention and promotion of all those involved.

\section{References}

Amaral, D. K. (2010) Histórias de (re)provação escolar: vinte e cinco anos depois (Dissertação de mestrado). Retrieved from http://www.teses.usp.br/teses/.../48/.../ DANIELE_KOHMOTO_AMARAL.pdf
Angelucci, C. B., Kalmus, J., Paparelli, R., \& Patto, M. H. S. (2004). O estado da arte da pesquisa sobre o fracasso escolar (1991-2002): Um estudo introdutório. Educação e Pesquisa, 30(1), 51-72. Retrieved from http://www.scielo.br/pdf/ep/ v30n1/a04v30n1.pdf

Asbahr, F. S. F., \& Lopes, J. S. (2006). A culpa é sua. Psicologia USP, 17(1), 53-73. doi: 10.1590/ S0103-65642006000100005

Barbour, R. (2009). Grupos focais (M. F. Duarte, Trad.). Porto Alegre: Artmed.

Bardin, L. (1977). Análise de conteúdo (L. Reto \& A. Pinheiro, Trad.). São Paulo: Edições 70/Livraria Martins Fontes.

Bassani, E., \& Pinel, H. (2011). Notas sobre a contribuição da obra de Maria Helena Souza Patto em um Programa de Pós-Graduação em Educação. Psicologia USP, 22(3), 551-567. doi: 10.1590/ S0103-65642011005000018

Brasil (1996). Congresso Nacional. Lei de Diretrizes e Bases da Educação Nacional - Lei 9.394 de 20 de dezembro de 1996.

Brasil (2010a). Conselho Nacional de Educação. Parecer CNE/CEB no 7/2010. Estabelece: Diretrizes Curriculares Nacionais Gerais para a Educação Básica.

Brasil (2010b). Conselho Nacional de Educação. Resolução CNE/CEB no 4/2010. Estabelece: Diretrizes Curriculares Nacionais Gerais para a Educação Básica.

Brasil (2012). Ministério da Saúde. Conselho Nacional de Saúde. Resolução 466. Retrieved from http://conselho.saude.gov.br/resoluces/2012/ Reso466.pdf

Bray, C., T., \& Leonardo, N. S. T. (2011). As queixas escolares na compreensão de educadoras de escola pública e privada. Revista Semestral da Associação Brasileira de Psicologia Escolar e Educacional, 15(2), 251-261. Retrieved from http://www.scielo.br/ pdf/pee/v15n2/v15n2a07.pdf

Bossa, N. A. (2002). Fracasso escolar: Um olhar psicopedagógico. Porto Alegre: Artmed.

Caldas, R. F. L. (2005). Fracasso escolar: Reflexões sobre uma história antiga, mas atual. Psicologia: Teoria e Prática, 7(1), 21-33. Retrieved from http://pepsic. bvsalud.org/pdf/ptp/v7n1/v7n1a03.pdf 
Chechia, V. A., \& Andrade, A. S. (2005). O desempenho escolar dos filhos na percepção de pais de alunos com sucesso e insucesso escolar. Estudos de Psicologia, 10(3), 431-440. Retrieved from http://www. redalyc.org/articulo.oa?id $=26110312$

Costa, R. P. B., Lima, M. C. P., \& Pinheiro, C. V. Q. (2010). Os impasses da educação na adolescência contemporânea. Boletim de Psicologia, LX(132), 97106. Retrieved from http://pepsic.bvsalud.org/ pdf/bolpsi/v60n132/v60n132a09.pdf

Damiani, M. F. (2006). Discurso pedagógico e fracasso escolar. Ensaio: Avaliação e Políticas Públicas em Educação, 14(53), 457-478. Retrieved from http:/ /www. scielo.br/pdf/ensaio/v14n53/a04v1453.pdf

Dhavan, P., Stigler, M. H., Perry, C. L., Arora, M., \& Reddy, K. S. (2010). Is tobacco use associated with academic failure among government school students in urban India? Journal of School, 80(11), 552-560. doi: 10.1111/j.1746-1561.2010.00541.x.

Faissol, K. F. \& Bastos, M. C. (2014) Projecto Refazer: Uma reflexão da reprovação a partir do olhar do aluno. Journal of Child and Adolescent Psychology, 5(1), 201-210. Retrieved from http://revistas.lis.ulusiada.pt/index.php/rpca/article/view/1132/1247

Farid, M. F. (2012). Causal attribution beliefs among school students in Pakistan. Interdisciplinary Journal of Contemporary Research in Business, 4(2), 411-424. Retrieved from http://journal-archieves19.webs. com/411-424.pdf

Flick, U. (2009). Desenho da pesquisa qualitativa (R, C, Costa, Trad.). Porto Alegre: Artmed.

Gauffin, K., Vinnerljung, B., Fridell, M., Hesse, M., \& Hjern, A. (2013). Childhood socio-economic status, school failure and drug abuse: A Swedish national cohort study. Addiction, 108(8), 1441-1449. doi:10.1111/add.12169

Gomes, C., \& Souza, V. L. T. (2009). Fracassos, representações e exclusões no processo de permanência na escola. Revista de Psicopedagogia, 26(79), 41-47. Retrieved from http://pepsic.bvsalud.org/pdf/ psicoped/v26n79/v26n79a06.pdf

González Rey, F. (2002). Pesquisa qualitativa e subjetividade: Caminhos e desafios. São Paulo: Thomson Learnig.

Gran, B. C., \& Nieto, M. A. P. (2013). El efecto del absentismo y el fracaso escolar en el consumo de tabaco, en una muestra de estudiantes de $3^{\circ}$ y $4^{\circ}$ de la educación secundaria obligatoria. Health and Addictions, 13(1), 53-58. Retrieved from https://dialnet. unirioja.es/servlet/articulo?codigo $=4343765$

Guler, M. P. D. (2013). Success and failure in science education: A focus group study on Turkish students. Journal of Baltic Science Education, 12(6), 716-729. Retrieved from http://journals.indexcopernicus. com/abstracted.php?level $=5 \&$ icid $=1080623$

Hancer, A. H. (2012). Reasons of academic failure in Turkish and Polish $6^{\text {th }}$ grade primary school students. International Journal of Academic Research - Part B, 4(4), 78-82. doi: 10.7813/2075-4124.2012/4-4/B.11

Hjörne, E., \& Säljö, R. (2014). Analysing and preventing school failure: Exploring the role of multi-professionality in pupil health team meetings. International Journal of Educational Research, 63, 5-14. doi: 10.1016/j.ijer.2012.09.005

Instituto Brasileiro de Geografia e Estatística (IBGE). Censo demográfico de 2010. Retrieved from http:// home/mapa_site.php3populacao

Ireland, V., Charlot, B., Gomes, C., Gusso, D., Carvalho, L. C. R., Fernandes, M., Ennafaa, R., \& Garcia, W. (2007). Repensando a escola. Brasília: UNESCO/ MEC/INEP.

Jacomini, M. A. (2010). Por que a maioria dos pais e alunos defende a reprovação? Cadernos de Pesquisa, 40(141), 895-919. Retrieved from http://www. scielo.br/pdf/cp/v40n141/v40n141a12.pdf

Kamal, M., \& Bener, A. (2009). Factors contributing to school failure among school children in a very fast developing Arabian society. Oman Medical Journal, 24(3), 212-217. doi: 10.5001/omj.2009.42

Lagana-Riordan, C., Aguilar, J., Franklin, C., Streeter, C. Kim, J. Tripodi, S., \& Hopson, L. (2011). At-risk students's perceptions of traditional schools and a solutions-focused public alternative school. Preventing School Failure, 55(3), 105-114. doi: 10.1080/10459880903472843

Lahire, B. (2004). As origens da desigualdade escolar. In A. Marchesi, \& C. H. Gil (Eds.), Fracasso escolar: Uma perspectiva multicultural (E. Rosa, Trad.; pp.6975). Porto Alegre: Artmed.

Laville, C., \& Dionne, J. (1999). A construção do saber: Manual de metodologia da pesquisa em ciências humanas (L. M. Siman, Trad.). Porto Alegre: Artes Médicas. 
Lopes, A. R., \& Teixeira, M. O. (2012). Projetos de carreira, autoeficácia e sucesso escolar em ambiente multicultural. Revista Brasileira de Orientação Profissional, 13(1), 7-14. Retrieved from http://pepsic. bvsalud.org/pdf/rbop/v13n1/03.pdf

Marchesi, A., \& Lucena, C. H. (2004). A representação social do fracasso escolar. In A. Marchesi, \& C. H. Gil (Eds.), Fracasso escolar: Uma perspectiva multicultural (E. Rosa, Trad.; pp.124-135). Porto Alegre: Artmed.

Martinelli, S., C., \& Aguena, E. C. (2011). La motivación en estudiantes de enseñanza fundamental y las creencias y actitudes de los padres. Revista IIPSI, 14(1), 53-63. Retrieved from http://sisbib.unmsm. edu.pe/BVRevistas/Investigacion_Psicologia/ v14_n1/pdf/a04.pdf

Martinelli, S. C., \& Genari. H. M. (2009). Relações entre desempenho escolar e orientações motivacionais. Estudos de Psicologia, 14(1), 13-21. doi: 10.1590/ S1413-294X2009000100003

Millones, D., Leeuwen, K., \& Ghesquière, P. (2013). Associations between psychosocial functioning and academic achievement: The Peruvian case. Universitas Psychologica, 12(3), 725-737. Retrieved from http://www.scielo.org.co/pdf/rups/v12n3/ v12n3a07.pdf

Mocetti, S. (2012). Educational choices and the selection process: Before and after compulsory schooling. Education Economics, 20(2), 189-209. doi:10.1080/09645291003726434

Neves, M. B. J., \& Almeida, S. F. C. (1996). O fracasso escolar na $5^{a}$ série, na perspectiva de alunos repetentes, seus pais e professores. Psicologia: Teoria \& Pesquisa, 12(2), 147-156.

Neves, L., \& Santiago, A. L. (2009). O uso de jogos teatrais na educação: Possibilidades diante do fracasso escolar. Revista Portuguesa de Pedagogia, 43(1), 53-76. Retrieved from http://iduc.uc.pt/index. php/rppedagogia/article/view/1259

Nunes, T. G., Pontes, F. A. R., Silva, L. I. C., \& Dell'Aglio, D. D. (2014). Fatores de risco e proteção na escola: Reprovação e expectativas de futuro de jovens paraenses. Revista Quadrimestral da Associação Brasileira de Psicologia Escolar e Educacional, 18(2), 203-210. doi: 10.1590/2175-3539/2014/0182732
Oliveira, L. C. F. (2002). Escola e família numa rede de des(encontros): Um estudo das representações de pais e professores. São Paulo: Cabral Editora e Livraria Universitária.

Oliveira, M., \& Freitas, H. (1997). Focus group - método qualitativo de pesquisa: Resgatando a teoria, instrumentalizando o seu planejamento. Porto Alegre: Editora da UFRGS.

Oliveira, F. N., \& Macedo, L. (2011). Resiliência e insucesso escolar: Uma reflexão sobre ás salas de aprendizagem. Estudos e Pesquisas em Psicologia, 11(3), 983-1004. Retrieved from http://www.e-publicacoes.uerj.br/index.php/revispsi/article/ view/8347/6146

Osti, A., \& Brenelli, R. P. (2013). Sentimentos de quem fracassa na escola: Análise das representações de alunos com dificuldades de aprendizagem. Psico-USF, 18(3), 417- 426. doi: 10.1590/S1413-82712013000300008

Paula, F. S., \& Tfouni, L. V. (2009). A persistência do fracasso escolar: Desigualdade e ideologia. Revista Brasileira de Orientação Profissional, 10(2), 117-127. Retrieved from http://pepsic.bvsalud.org/pdf/ rbop/v10n2/v10n2a12.pdf

Patto, M. H. S. (1990). A producãa do fracasso escolar: Histórias de submissão e rebeldia. São Paulo: Casa do Psicólogo.

Pershey, M. G. (2010). A comparison of African American students' self-perceptions of schoolcompetence with their performance on state-mandated achievement tests and normed tests of oral and written language and reading. Preventing School Failure, 55(1), 53-62. doi: 10.1080/10459880903472835

Robson, C. (1995). Real word research: A resource for scientist and practiotioner-researchs. Oxford: U.K.: Blackwell.

Rumberger, R. W. (2011). Introdution. In R. W. Rumberger, Droping out (pp. 1-19). Retrieved from http:// education.ucsb.edu/rumberger/book/ch1.pdf

Secretaria Municipal de Educação de São Leopoldo SMED-SL (2012). Projeto Seguindo em Frente 2012. Arquivo da Secretaria Municipal de Educação, São Leopoldo, RS.

Travi, M. G. G., Oliveira-Menegotto, L. M., \& Santos, G. A. (2009). A escola contemporânea diante do fracasso escolar. Revista Psicopedagogia, 26(81), 
425-434. Retrieved from http://pepsic.bvsalud. org/pdf/psicoped/v26n81/v26n81a10.pdf

Zucoloto P. C. S. V., \& Patto, M. H. S. (2007). O médico higienista na escola: As origens históricas da medicalização do fracasso escolar. Revista Brasileira de Crescimento Desenvolvimento Humano, 17(1), 136-145.
Retrieved from http://pepsic.bvsalud.org/pdf/ rbcdh/v17n1/13.pdf

Recebido em: 08/06/2015

Reformulado em: 29/07/2015

Aprovado em: 14/08/2015

Nota das autoras:

Artigo derivado da dissertação de mestrado de Fernanda Aparecida Szareski Pezzi, realizada sob a orientação da professora Dra. Angela Helena Marin, apresentada no Programa de Pós-Graduação em Psicologia da Universidade do Vale do Rio dos Sinos - Unisinos.

Sobre as autoras:

Fernanda Aparecida Szareski Pezzi é psicóloga, mestre em Psicologia pela Universidade do Vale do Rio dos Sinos (Unisinos), RS e professora no curso de graduação em Psicologia da Sociedade Educacional Três de Maio (Setrem).

E-mail: nandaszareski@yahoo.com.br

Tagma Marina Schneider Donelli é psicóloga, mestre e doutora em Psicologia pelo Programa de Pós-Graduação em Psicologia da Universidade Federal do Rio Grande do Sul e professora dos Cursos de Graduação e de Pós-graduação em Psicologia da Universidade do Vale do Rio dos Sinos - Unisinos, RS.

E-mail:tagmad@unisinos.br

Angela Helena Marin é psicóloga, mestre e doutora em Psicologia pelo Programa de Pós-Graduação em Psicologia da Universidade Federal do Rio Grande do Sul e professora dos cursos de graduação e de pós-graduação em Psicologia da Universidade do Vale do Rio dos Sinos - Unisinos, RS.

E-mail: angelahm@unisinos.br

Contato com as autoras:

Fernanda Aparecida Szareski Pezzi

Sociedade Educacional Três de Maio - Setrem

Avenida Santa Rosa, 2405 - Centro

CEP: 98910-000

Três de Maio - RS, Brasil 